\title{
Statins, fibrates, thiazolidinediones and resveratrol as adjunctive therapies in sepsis: could mitochondria be a common target?
}

\author{
Jerome Morel ${ }^{1}$ and Mervyn Singer ${ }^{2^{*}}$
}

\footnotetext{
* Correspondence: m.singer@ucl.ac.uk ${ }^{2}$ Bloomsbury Institute of Intensive Care Medicine, University College London, London WC1E 6BT, UK Full list of author information is available at the end of the article
}

\begin{abstract}
Through their pleiotropic actions, statins, fibrates, thiazolidinediones and resveratrol can target multiple mechanisms involved in sepsis. Their actions on mitochondrial function are of interest in a pathological state where bioenergetic failure may play a key role in the development of organ dysfunction. We review these four drug groups as potential adjunctive therapies in sepsis with a particular focus upon mitochondria. Systematic review of clinical and experimental trials was done with a literature search using the PubMed database. Search terms included statins, fibrates, thiazolidinediones, resveratrol, mitochondria, sepsis, peroxisome proliferator-activated receptors, inflammation, oxidative stress and organ dysfunction. With the exception of statins, most of the compelling evidence for the use of these agents in sepsis comes from the experimental literature. The agents all exert anti-inflammatory and anti-oxidant properties, plus protective effects against mitochondrial dysfunction and stimulation of mitochondrial biogenesis. Improved outcomes (organ dysfunction, survival) have been reported in a variety of sepsis models. Notably, positive outcome effects were more commonly seen when the agents were given as pre- rather than post-treatment of sepsis. Statins, fibrates, thiazolidinediones and resveratrol prevent sepsis-induced injury to organs and organelles with outcome improvements. Their effects on mitochondrial function may be integral in offering this protection. Definitive clinical trials are needed to evaluate their utility in septic patients or those at high risk of developing sepsis.
\end{abstract}

Keywords: Statin; Fibrates; Thiazolidinedione; Resveratrol; Mitochondria; Sepsis; Pleiotropic effects; Peroxisome proliferator-activated receptors

\section{Review}

Introduction

Severe sepsis is characterized by a dysregulated systemic inflammatory response to infection resulting in acute multiple organ dysfunction (MOF) and a high mortality rate. The pathophysiology of sepsis-induced MOF remains incompletely understood but a growing body of evidence supports impairment of cellular oxygen utilization as a key mechanism [1-4]. Considerable enthusiasm has recently surrounded the potential beneficial effect of fibrates, thiazolidinediones (TZD) and, particularly, statins as adjunctive therapies for sepsis [5-9]. Some experimental studies also suggest a role for resveratrol [10-14]. However, most of these positive outcomes have been generated in laboratory 
models of sepsis such as caecal ligature and puncture or injection of endotoxin. The discrepancies observed to date between human and experimental studies may relate to the difficulty in reproducing the complexity of human sepsis and/or the use of doses far in excess of those currently used in clinical practice. Prospective clinical trial data are insufficient, particularly for fibrates and TZDs [15-17], and non-existent for resveratrol.

Statins, fibrates and TZDs modulate lipid and glucose metabolism. Resveratrol, a phenol constituent of red wine, is not available as a stand-alone medication but has been reported to slow down carcinogenesis, cardiovascular disease and ischaemic injury [18]. All four classes exert pleiotropic effects through mechanisms that remain incompletely understood $[6,8,18,19]$. Immune-inflammatory modulation is a common property; however, several authors have also underlined effects on mitochondrial function [14,20-23]. This may be highly pertinent to critical illness as bioenergetic dysfunction is implicated in the pathophysiology of sepsis-induced multi-organ failure [4].

In view of this burgeoning interest, it is timely to summarize the main recognized mechanisms of these agents, including their actions on mitochondria, and to offer a critical review of currently available experimental and clinical data.

\section{Modes of action}

Statins In addition to lowering low-density lipoprotein (LDL) cholesterol, statins exhibit a wide range of other biological effects. Statins inhibit 3-hydroxy-3-methyl-glutarylcoenzymeA (HMGCoA) reductase, a key enzyme in the mevalonate pathway. Mevalonate is a precursor for cholesterol, ubiquinone and isoprenoids (Figure 1) [24]. Thus, statins

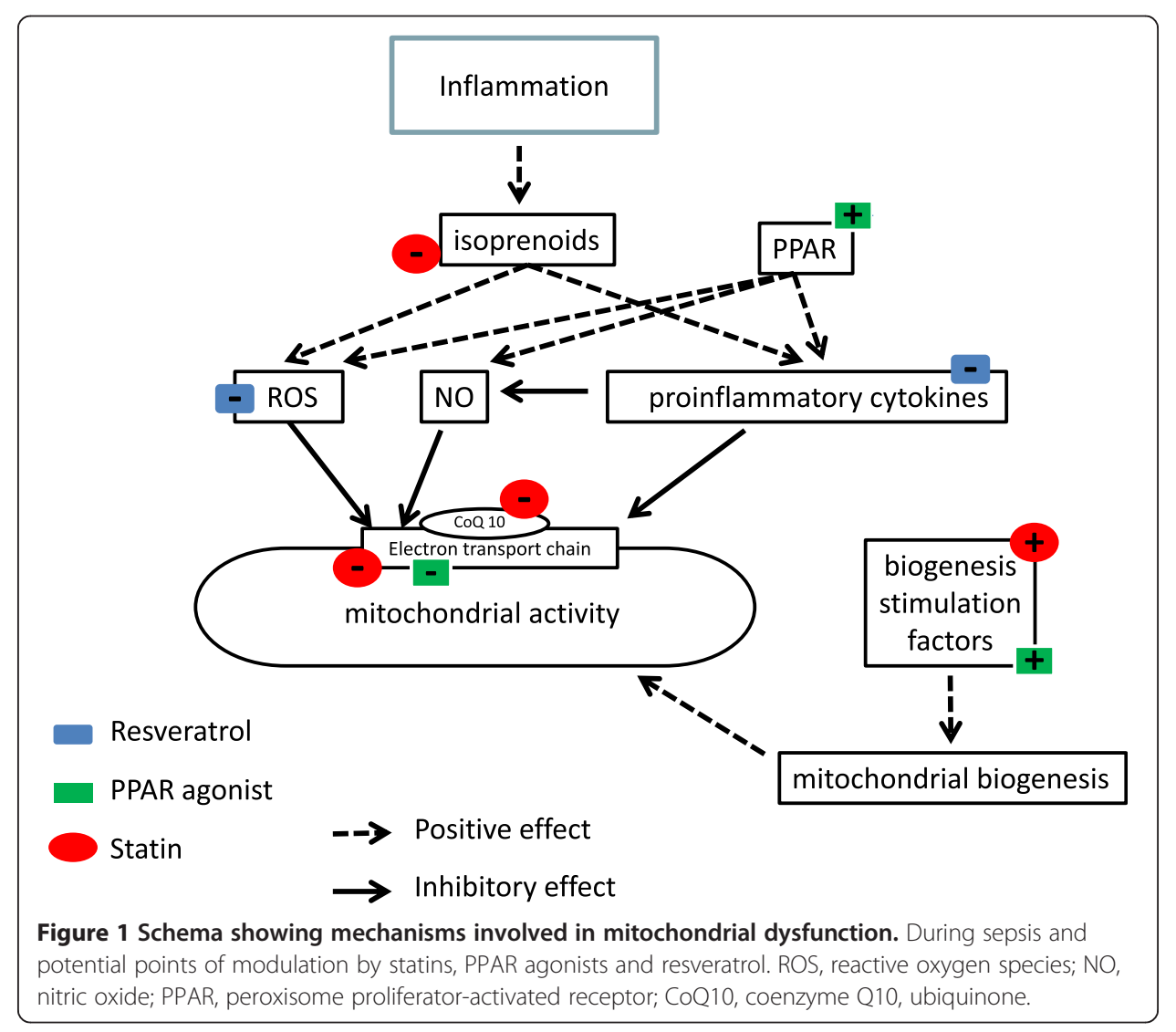


can decrease all three end products but, as a consequence of enzyme affinity, mainly reduce cholesterol production.

Ubiquinone is both an electron carrier within the mitochondrial electron transport chain that generates ATP and a powerful anti-oxidant [21]. While several clinical and experimental studies have reported that statins decreased the ratio of plasma ubiquinone to LDL (its natural carrier), its effects on tissue ubiquinone levels are more controversial. It may be an important mechanism underlying statin-induced myopathy [25].

Isoprenoids (farnesyl pyrophosphate and geranyl pyrophosphate) serve as lipid attachments and activators for various signalling molecules such as G-protein and GTP-binding protein (Ras and Ras-like protein) [24], which have been associated with reactive oxygen species (ROS) production and activation of pro-inflammatory pathways (reviewed by Blanco-Colio et al. [26]). The pleiotropic effects of statins have been associated with decreased levels of these small proteins [27]. Both in vivo and in vitro studies show that statins can induce cellular accumulation of endothelial nitric oxide synthase, inhibit expression of adhesion molecules and chemokines that recruit inflammatory cells, inhibit expression of pro-coagulant factors, induce production of anticoagulant substances, increase apoptosis, decrease oxidative stress, and modulate the adaptive immune system (reviewed by Terblanche et al. [8]). In a volunteer study, pretreatment with simvastatin prior to lipopolysaccharide (LPS) attenuated the upregulation of Toll-like receptor 2 and 4 surface expression on circulating monocytes [28]. How many of these effects are related to lowering LDL cholesterol remains uncertain. Of note, squalestatin, a selective inhibitor of the synthesis of sterol derivatives, has no anti-inflammatory effect compared to statins [24].

Statins can affect skeletal muscle mitochondria in vitro by inhibiting respiratory chain complexes and oxidative capacity [29,30], decreasing mitochondrial membrane potential [30], uncoupling oxidative phosphorylation [30], inducing mitochondrial swelling and apoptosis [30] and decreasing mitochondrial density [31] (Figure 1). However, no clear relationship has been documented between a decrease in ubiquinone and alterations in mitochondrial function. Hydrophilic statins (e.g. pravastatin) are much less 'mitotoxic' compared to lipophilic statins such as cerivastatin, fluvastatin, atorvastatin and simvastatin [30]. It is noteworthy that the toxic effects of atorvastatin are mostly observed with doses that are much higher than those prescribed to patients. The delayed metabolism of statins seen in critical illness may result in very high plasma levels so the risk of toxicity would potentially increase; however, this would be difficult to distinguish in an unstable patient with concurrent multi-organ failure [32]. As discussed later, these 'toxic' effects may, paradoxically, offer some protective effects during sepsis. Recently, Bouitbir et al. reported that statin-treated patients who underwent cardiac surgery had decreased oxidative stress, enhanced oxidative capacity, and a marked augmentation of mRNA expression of the peroxisome proliferator-activated receptor (PPAR) gamma co-activators $1 \alpha(P G C-1 \alpha)$ and $1 \beta(P G C-1 \beta)$. PGC- $1 \alpha$ is the main regulator of mitochondrial biogenesis, i.e. new protein turnover [20]. This study raises new insights regarding the action of statins, but the clinical impact remains to be explored.

Fibrates and thiazolidinediones PPARs are ligand-activated transcription factors that belong to the nuclear receptor superfamily. Once activated by ligands, PPARs form a 
heterodimer with the retinoic X receptor (RXR) that allows recruitment of a set of co-activators or co-repressors [6,33]. This heterodimer binds to the PPAR response element within the promoter region of its target genes, provoking either expression or repression. PPAR inhibits expression of pro-inflammatory cytokines through direct or indirect actions on pro-inflammatory transcription factors (NF-kB, STAT, AP-1) $[6,34]$.

Fibrates are synthetic ligands of peroxisome proliferator-activated receptor- $\alpha$ (PPAR- $\alpha$ ). Fibrates are used for treating dyslipidaemias, lowering both triglyceride and LDL cholesterol levels. They also ameliorate insulin resistance and glucose intolerance [5,35]. The PPAR- $\alpha$ receptor is expressed mainly in brown fat and liver but has been found in many other cells $[5,36]$.

TZDs are synthetic ligands of peroxisome proliferator-activated receptor- $\gamma$ (PPAR- $\gamma$ ). While most of their effects appear dependent upon PPAR activation, TZDs could also exert anti-inflammatory effects in macrophages via a PPAR-independent pathway [37]. Thiazolidinediones are drugs used for managing type II diabetes mellitus and the metabolic syndrome. Rosiglitazone, pioglitazone, troglitazone, rivoglitazone and ciglitazone are members of this therapeutic class. However, most have been withdrawn from the market due to adverse effects on heart. The PPAR- $\gamma$ receptor is highly expressed in adipose tissue and, to a lesser extent, in intestine, immune and stem cells [6]. Activation of these receptors decreases insulin resistance and modifies lipid storage. A timedependent downregulation of PPAR- $\gamma$ expression has been reported in experimental sepsis that is partially restored by TZDs [34].

After various inflammatory insults, in vivo and in vitro studies have shown that both fibrates and TZDs improved endothelial dysfunction [38,39], inhibited expression of adhesion molecules and inflammatory cytokines $[40,41]$ and decreased oxidative stress and nitric oxide production [39,42]. Fibrates can inhibit coagulation [38,43] and may improve haemorheologic parameters [44]. TZDs increase plasma adiponectin levels [45] and may initiate macrophage apoptosis via caspase-3 activation [46].

Both drug groups also impair mitochondrial function, at least in vitro, via direct inhibition of mitochondrial respiration (mainly complex I) [47], by membrane depolarization [48] and through increases in uncoupled respiration [49,50] (Figure 1). At lower doses, TZDs enhanced mitochondrial potential and promoted lymphocyte survival [51]. Several studies report that PPAR- $\gamma$ agonists induce mitochondrial biogenesis by mechanisms that are not fully understood but could be mediated, at least in part, via activation of PGC- $1 \alpha$ $[52,53]$. None of these studies have been carried out in sepsis, where early activation of mitochondrial biogenesis has been associated with survival [54].

Statins, fibrates and TZDs can act synergistically to affect some of the pathways previously described [55]. For example, patients with cardiovascular disease showed additive anti-inflammatory effect when statins were given in combination with PPAR- $\gamma$ agonists [56].

Resveratrol Resveratrol is a natural phenol present in many plants but especially abundant in red grapes, peanuts and mulberries [18]. It exerts beneficial effects in experimental sepsis when administered either before or shortly after the septic insult. The mechanisms involved are not yet clearly defined. Recent research has demonstrated that resveratrol activates the silent mating type information regulator 2 homolog 1 
(SIRT1), which is a key regulator of cellular defenses and cell survival in response to stress [57]. Of specific interest in sepsis is the interaction between SIRT1 and mitochondrial biogenesis [23,57]. Resveratrol has also been shown to downregulate the proinflammatory response $[14,58]$ and to have anti-oxidant properties $[11,57]$.

Experimental and clinical evidence of statins, fibrates and thiazolidinedione effects in sepsis

Statins In a murine model of sepsis, simvastatin pre-treatment markedly improved survival times (median $128 \mathrm{~h}$ versus $28 \mathrm{~h}, p<0.005$ ) [59]. Even treatment commencing after the onset of sepsis improved survival times, though less impressively (median $37 \mathrm{~h}$ versus $23 \mathrm{~h}$ for placebo, $p<0.05$ ) [60]. In another study, 3 days of simvastatin pretreatment improved survival and reduced sepsis-induced acute kidney injury by direct effects on the renal microvasculature, reversal of tubular hypoxia and a decrease in systemic inflammation [61]. In a rat model of peritonitis, 30 days' pre-treatment with high doses of simvastatin or atorvastatin prevented hepatic mitochondrial enzyme dysfunction; however, no improvement was seen in liver dysfunction while mortality differences were not reported [62].

Several observational studies have reported significant survival improvement in large cohorts of patients on statin therapy who suffer from bacterial [63-66] or viral infections [67]. However, some authors argue this simply represents a healthy user effect $[68,69]$. An association with harm was even reported in a study of infections poststroke [70]. Four double-blind, placebo-controlled, randomized clinical studies have been performed to examine the impact of either introducing [71-73] or continuing [74] statin therapy in patients with sepsis. Statin treatment was not associated with a significant decrease in pro-inflammatory markers compared to placebo [71,73,74]. In a different context, healthy volunteers randomized to statin pre-treatment and subsequently challenged with inhaled LPS manifested less pulmonary and systemic inflammation [75]. While one study showed a reduction in the progression to severe sepsis in patients taking statins, albeit with a similar rate of intensive care admissions between the statin and control groups [72], this was not confirmed by other studies [71,73,74]. Finally, stopping statin therapy in septic patients was not associated with worse outcomes [74]. As mentioned previously, statins should be used with caution in critically ill patients due to their unpredictable pharmacokinetics and the amplifying effect related to coadministration of drugs with cytochrome P450 inhibitory effects [32]. Opinions on the utility of statins in sepsis thus remain mixed.

Fibrates A few studies have reported improved outcomes following fibrate therapy in experimental sepsis $[38,76]$. For example, influenza-infected mice pre-treated with gemfibrozil had a 54\% reduction in mortality [76]. In patients with chronic hepatitis C and hyperlipidaemia, bezafibrate given as adjunctive therapy decreased plasma virus titres and improved liver dysfunction [16]. Fibrates also prevented muscular atrophy [76], a major problem occurring with sepsis. Protective mechanisms need to be elucidated but a decrease in atrogen and myostatin expression has been shown with fibrates therapy in a rat model of chronic inflammation [77].

Children with severe sepsis had decreased leukocyte PPAR- $\alpha$ expression, and this was related to disease severity [78]. In a randomized controlled trial in children with severe burn injury, in which condition mitochondrial dysfunction has been previously 
observed [79], mitochondrial biogenesis and oxidative phosphorylation were improved with fenofibrates therapy commenced within a week post-burn [35].

Thiazolidinediones In different models of sepsis, pre- or post-treatment with TZD improved outcomes, blunted pro-inflammatory cytokine production and reduced organ injury $[34,42,45,80,81]$. A recent study in endotoxic mice revealed protection from the PPAR- $\gamma$ agonist, rosiglitazone with less reduction in mitochondrial content, improved cardiac dysfunction and better survival rates [82]. On the other hand, the PPAR- $\alpha$ agonist WY-14643 offered no protection. Pioglitazone given to healthy volunteers after endotoxin challenge did not affect plasma levels of TNF $\alpha$, IL-6 levels or the adhesion molecule VCAM ([83] abstract). An improvement in blood pressure was reported in one study investigating ciglitazone administration following caecal ligation and puncture in rats, but there was no effect on survival [34]. No observational clinical trials are available with TZDs; however, users appear to be at higher risk of pneumonia or lower respiratory tract infection [84]. The risk of heart attack described with this drug has discouraged its widespread use and thus the possibility of conducting large-scale observational studies [85]. Several studies reported a significant reduction in weight loss with TZDs following different types of infectious challenge [42,86,87]. This observation has not been specifically studied but TZDs block activation of NF- $\mathrm{kB}$ [34], a main activator of muscle wasting [88], in addition to their effects on stimulating PGC-1 $\alpha$ and mitochondrial biogenesis [89].

The role of TDZs is not limited to bacterial infection. In a randomized placebocontrolled trial of 140 patients suffering from non-severe malaria, Boggild et al. reported in faster blood parasite clearance and a more rapid decrease in inflammatory biomarker levels (IL-6 and monocyte chemoattractant protein-1) in those given rosiglitazone as adjunctive therapy [15]. After a lethal dose of C. Albicans, mice post-treated with pioglitazone had better outcomes and less renal dysfunction [87]. Rosiglitazone also dramatically improved survival in a murine influenza model $[86,90]$ and reduced HIV-1 replication in lymphocytes and brain macrophages in an experimental model of HIV-1 encephalitis [91].

Resveratrol Resveratrol improved sepsis-induced acute organ injury [10,12,13], but the effect on mortality was uncertain [12,14]. In different cell or tissue types, resveratrol upregulated PGC-1 $\alpha$ and decreased mitochondrial ROS production with a consequent increase in mitochondrial size, DNA content and mitochondrial respiratory enzymatic activity $[14,23]$.

\section{Conclusions}

Through their pleiotropic actions, statins, fibrates, thiazolidinediones and resveratrol can target multiple mechanisms involved in sepsis. These are summarized in the schema shown in Figure 1. Their actions on mitochondrial function and, particularly mitochondrial biogenesis, are of interest in a pathological state where mitochondrial dysfunction may play a key role in the development of organ dysfunction. We can speculate that inhibitory effects of these agents, in particular statins, on mitochondrial function in otherwise healthy patients may potentially offer some benefit in the septic 
state. By decreasing mitochondrial activity and membrane potential, production of mitochondrial reactive oxygen species would decrease and this may result in a greater degree of cell and mitochondrial protection. Further clinical and experimental studies are warranted to reveal whether benefit can be shown in septic patient populations or in those at high risk of developing sepsis.

\begin{abstract}
Abbreviations
HMGCOA: 3-hydroxy-3-methyl-glutaryl-coenzymeA; LDL: low-density lipoprotein; LPS: lipopolysaccharide; PGC-1ß: peroxisome proliferator activated receptor $\gamma$ coactivator $1 \beta$; PGC-1a: peroxisome proliferator activated receptor $\gamma$ coactivator 1 a; PPAR: peroxisome proliferator-activated receptor; TZD: thiazolidinediones; ROS: reactive oxygen species; SIRT1: silent mating type information regulator 2 homolog-1.
\end{abstract}

\title{
Competing interests
}

The authors declare that they have no competing interests.

\section{Authors' contributions}

JM and MS wrote the article. Both authors read and approved the final manuscript.

\section{Author details}

${ }^{1}$ Département d'anesthésie réanimation, Centre Hospitalier Universitaire de Saint Etienne, 42055 Saint Etienne, France.

${ }^{2}$ Bloomsbury Institute of Intensive Care Medicine, University College London, London WC1E 6BT, UK.

Received: 10 October 2013 Accepted: 30 January 2014

Published: 17 April 2014

\section{References}

1. Brealey D, Brand M, Hargreaves I, Heales S, Land J, Smolenski R, Davies NA, Cooper CE, Singer M (2002) Association between mitochondrial dysfunction and severity and outcome of septic shock. Lancet 360:219-223

2. Brealey D, Karyampudi S, Jacques TS, Novelli M, Stidwill R, Taylor V, Smolenski RT, Singer M (2004) Mitochondrial dysfunction in a long-term rodent model of sepsis and organ failure. Am J Physiol Regul Integr Comp Physiol 286:R491-R497

3. Bozza FA, D'Avila JC, Ritter C, Sonneville R, Sharshar T, Dal-Pizzol F (2013) Bioenergetics, mitochondrial dysfunction, and oxidative stress in the pathophysiology of septic encephalopathy. Shock 39(Suppl 1):10-16

4. Singer M (2007) Mitochondrial function in sepsis: acute phase versus multiple organ failure. Crit Care Med 35:S441-S448

5. Clark RB (2002) The role of PPARs in inflammation and immunity. J Leukoc Biol 71:388-400

6. Schmidt MV, Brune B, von Knethen A (2010) The nuclear hormone receptor PPARgamma as a therapeutic target in major diseases. Sci World J 10:2181-2197

7. Zingarelli B, Cook JA (2005) Peroxisome proliferator-activated receptor-gamma is a new therapeutic target in sepsis and inflammation. Shock 23:393-399

8. Terblanche M, Almog Y, Rosenson RS, Smith TS, Hackam DG (2007) Statins and sepsis: multiple modifications at multiple levels. Lancet Infect Dis 7:358-368

9. Fedson DS (2006) Pandemic influenza: a potential role for statins in treatment and prophylaxis. Clin Infect Dis 43:199-205

10. Gacar N, Gocmez S, Utkan T, Gacar G, Komsuoglu I, Tugay M, Utkan NZ (2012) Effects of resveratrol on ileal smooth muscle reactivity in polymicrobial sepsis model. J Surg Res 174:339-343

11. Hao E, Lang F, Chen Y, Zhang H, Cong X, Shen X, Su G (2013) Resveratrol alleviates endotoxin-induced myocardial toxicity via the Nrf2 transcription factor. PLoS One 8:e69452

12. Holthoff JH, Wang Z, Seely KA, Gokden N, Mayeux PR (2012) Resveratrol improves renal microcirculation, protects the tubular epithelium, and prolongs survival in a mouse model of sepsis-induced acute kidney injury. Kidney Int 81:370-378

13. Kolgazi M, Sener G, Cetinel S, Gedik N, Alican I (2006) Resveratrol reduces renal and lung injury caused by sepsis in rats. J Surg Res 134:315-321

14. Smeding L, Leong-Poi H, Hu P, Shan Y, Haitsma JJ, Horvath E, Furmli S, Masoom H, Kuiper JW, Slutsky AS (2012) Salutary effect of resveratrol on sepsis-induced myocardial depression. Crit Care Med 40:1896-1907

15. Boggild AK, Krudsood S, Patel SN, Serghides L, Tangpukdee N, Katz K, Wilairatana P, Liles WC, Looareesuwan S, Kain KC (2009) Use of peroxisome proliferator-activated receptor gamma agonists as adjunctive treatment for Plasmodium falciparum malaria: a randomized, double-blind, placebo-controlled trial. Clin Infect Dis 49:841-849

16. Fujita N, Kaito M, Kai M, Sugimoto R, Tanaka H, Horiike S, Konishi M, Iwasa M, Watanabe S, Adachi Y (2006) Effects of bezafibrate in patients with chronic hepatitis $C$ virus infection: combination with interferon and ribavirin. J Viral Hepat 13:441-448

17. Thomsen RW, Hundborg HH, Johnsen SP, Pedersen L, Sorensen HT, Schonheyder HC, Lervang HH (2006) Statin use and mortality within 180 days after bacteremia: a population-based cohort study. Crit Care Med 34:1080-1086

18. Baur JA, Sinclair DA (2006) Therapeutic potential of resveratrol: the in vivo evidence. Nat Rev Drug Discov 5:493-506

19. Tsimihodimos V, Miltiadous G, Daskalopoulou SS, Mikhailidis DP, Elisaf MS (2005) Fenofibrate: metabolic and pleiotropic effects. Curr Vasc Pharmacol 3:87-98

20. Bouitbir J, Charles AL, Echaniz-Laguna A, Kindo M, Daussin F, Auwerx J, Piquard F, Geny B, Zoll J (2012) Opposite effects of statins on mitochondria of cardiac and skeletal muscles: a 'mitohormesis' mechanism involving reactive oxygen species and PGC-1. Eur Heart J 33:1397-1407 
21. Brealey DA, Singer M, Terblanche M (2011) Potential metabolic consequences of statins in sepsis. Crit Care Med 39:1514-1520

22. Feinstein DL, Spagnolo A, Akar C, Weinberg G, Murphy P, Gavrilyuk V, Dello Russo C (2005) Receptor-independent actions of PPAR thiazolidinedione agonists: is mitochondrial function the key? Biochem Pharmacol 70:177-188

23. Lagouge M, Argmann C, Gerhart-Hines Z, Meziane H, Lerin C, Daussin F, Messadeq N, Milne J, Lambert P, Elliott P (2006) Resveratrol improves mitochondrial function and protects against metabolic disease by activating SIRT1 and PGC-1alpha. Cell 127:1109-1122

24. Diomede L, Albani D, Sottocorno M, Donati MB, Bianchi M, Fruscella P, Salmona M (2001) In vivo anti-inflammatory effect of statins is mediated by nonsterol mevalonate products. Arterioscler Thromb Vasc Biol 21:1327-1332

25. Marcoff L, Thompson PD (2007) The role of coenzyme Q10 in statin-associated myopathy: a systematic review. J Am Coll Cardiol 49:2231-2237

26. Blanco-Colio LM, Tunon J, Martin-Ventura JL, Egido J (2003) Anti-inflammatory and immunomodulatory effects of statins. Kidney Int 63:12-23

27. Jain MK, Ridker PM (2005) Anti-inflammatory effects of statins: clinical evidence and basic mechanisms. Nat Rev Drug Discov 4:977-987

28. Niessner A, Steiner S, Speidl WS, Pleiner J, Seidinger D, Maurer G, Goronzy JJ, Weyand CM, Kopp CW, Huber K (2006) Simvastatin suppresses endotoxin-induced upregulation of toll-like receptors 4 and 2 in vivo. Atherosclerosis 189:408-413

29. Mullen PJ, Zahno A, Lindinger P, Maseneni S, Felser A, Krahenbuhl S, Brecht K (2011) Susceptibility to simvastatininduced toxicity is partly determined by mitochondrial respiration and phosphorylation state of Akt. Biochim Biophys Acta 1813:2079-2087

30. Kaufmann P, Torok M, Zahno A, Waldhauser KM, Brecht K, Krahenbuhl S (2006) Toxicity of statins on rat skeletal muscle mitochondria. Cell Mol Life Sci 63:2415-2425

31. Paiva H, Thelen KM, Van Coster R, Smet J, De Paepe B, Mattila KM, Laakso J, Lehtimaki T, von Bergmann K, Lutjohann D (2005) High-dose statins and skeletal muscle metabolism in humans: a randomized, controlled trial. Clin Pharmacol Ther 78:60-68

32. Kruger PS, Freir NM, Venkatesh B, Robertson TA, Roberts MS, Jones M (2009) A preliminary study of atorvastatin plasma concentrations in critically ill patients with sepsis. Intensive Care Med 35:717-721

33. Kaplan JM, Denenberg A, Monaco M, Nowell M, Wong H, Zingarelli B (2010) Changes in peroxisome proliferatoractivated receptor-gamma activity in children with septic shock. Intensive Care Med 36:123-130

34. Zingarelli B, Sheehan M, Hake PW, O'Connor M, Denenberg A, Cook JA (2003) Peroxisome proliferator activator receptor-gamma ligands, 15-deoxy-Delta(12,14)-prostaglandin J2 and ciglitazone, reduce systemic inflammation in polymicrobial sepsis by modulation of signal transduction pathways. J Immunol 171:6827-6837

35. Cree MG, Zwetsloot JJ, Herndon DN, Qian T, Morio B, Fram R, Sanford AP, Aarsland A, Wolfe RR (2007) Insulin sensitivity and mitochondrial function are improved in children with burn injury during a randomized controlled trial of fenofibrate. Ann Surg 245:214-221

36. Braissant O, Foufelle F, Scotto C, Dauca M, Wahli W (1996) Differential expression of peroxisome proliferator-activated receptors (PPARs): tissue distribution of PPAR-alpha, -beta, and -gamma in the adult rat. Endocrinology 137:354-366

37. Chawla A, Barak Y, Nagy L, Liao D, Tontonoz P, Evans RM (2001) PPAR-gamma dependent and independent effects on macrophage-gene expression in lipid metabolism and inflammation. Nat Med 7:48-52

38. Wiel E, Lebuffe G, Robin E, Gasan G, Corseaux D, Tavernier B, Jude B, Bordet R, Vallet B (2005) Pretreatment with peroxysome proliferator-activated receptor alpha agonist fenofibrate protects endothelium in rabbit Escherichia coli endotoxin-induced shock. Intensive Care Med 31:1269-1279

39. Goya K, Sumitani S, Xu X, Kitamura T, Yamamoto H, Kurebayashi S, Saito H, Kouhara H, Kasayama S, Kawase I (2004) Peroxisome proliferator-activated receptor alpha agonists increase nitric oxide synthase expression in vascular endothelial cells. Arterioscler Thromb Vasc Biol 24:658-663

40. Jiang C, Ting AT, Seed B (1998) PPAR-gamma agonists inhibit production of monocyte inflammatory cytokines. Nature 391:82-86

41. Delerive P, De Bosscher K, Besnard S, Vanden Berghe W, Peters JM, Gonzalez FJ, Fruchart JC, Tedgui A, Haegeman G, Staels B (1999) Peroxisome proliferator-activated receptor alpha negatively regulates the vascular inflammatory gene response by negative cross-talk with transcription factors NF-kappaB and AP-1. J Biol Chem 274:32048-32054

42. Cuzzocrea S, Pisano B, Dugo L, lanaro A, Patel NS, Di Paola R, Genovese T, Chatterjee PK, Fulia F, Cuzzocrea E (2004) Rosiglitazone, a ligand of the peroxisome proliferator-activated receptor-gamma, reduces the development of nonseptic shock induced by zymosan in mice. Crit Care Med 32:457-466

43. Nilsson L, Takemura T, Eriksson P, Hamsten A (1999) Effects of fibrate compounds on expression of plasminogen activator inhibitor-1 by cultured endothelial cells. Arterioscler Thromb Vasc Biol 19:1577-1581

44. Frost RJ, Otto C, Geiss HC, Schwandt P, Parhofer KG (2001) Effects of atorvastatin versus fenofibrate on lipoprotein profiles, low-density lipoprotein subfraction distribution, and hemorheologic parameters in type 2 diabetes mellitus with mixed hyperlipoproteinemia. Am J Cardiol 87:44-48

45. Tsujimura Y, Matsutani T, Matsuda A, Kutsukake M, Uchida E, Sasajima K, Tamura K (2011) Effects of pioglitazone on survival and omental adipocyte function in mice with sepsis induced by cecal ligation and puncture. J Surg Res 171:e215-e221

46. Chinetti G, Griglio S, Antonucci M, Torra IP, Delerive P, Majd Z, Fruchart JC, Chapman J, Najib J, Staels B (1998) Activation of proliferator-activated receptors alpha and gamma induces apoptosis of human monocyte-derived macrophages. J Biol Chem 273:25573-25580

47. Brunmair B, Lest A, Staniek K, Gras F, Scharf N, Roden M, Nohl H, Waldhausl W, Furnsinn C (2004) Fenofibrate impairs rat mitochondrial function by inhibition of respiratory complex I. J Pharmacol Exp Ther 311:109-114

48. Zhou S, Wallace KB (1999) The effect of peroxisome proliferators on mitochondrial bioenergetics. Toxicol Sci 48:82-89

49. Zungu M, Young ME, Stanley WC, Essop MF (2009) Chronic treatment with the peroxisome proliferator-activated receptor alpha agonist Wy-14,643 attenuates myocardial respiratory capacity and contractile function. Mol Cell Biochem 330:55-62 
50. Nadanaciva S, Rana P, Beeson GC, Chen D, Ferrick DA, Beeson CC, Will Y (2012) Assessment of drug-induced mitochondrial dysfunction via altered cellular respiration and acidification measured in a 96-well platform. J Bioenerg Biomembr 44:421-437

51. Wang YL, Frauwirth KA, Rangwala SM, Lazar MA, Thompson CB (2002) Thiazolidinedione activation of peroxisome proliferator-activated receptor gamma can enhance mitochondrial potential and promote cell survival. J Biol Chem 277:31781-31788

52. Bolten CW, Blanner PM, McDonald WG, Staten NR, Mazzarella RA, Arhancet GB, Meier MF, Weiss DJ, Sullivan PM, Hromockyj AE (2007) Insulin sensitizing pharmacology of thiazolidinediones correlates with mitochondrial gene expression rather than activation of PPAR gamma. Genet Regul Syst Biol 1:73-82

53. Pardo R, Enguix N, Lasheras J, Feliu JE, Kralli A, Villena JA (2011) Rosiglitazone-induced mitochondrial biogenesis in white adipose tissue is independent of peroxisome proliferator-activated receptor gamma coactivator-1alpha. PLoS One 6:e26989

54. Carre JE, Orban JC, Re L, Felsmann K, Iffert W, Bauer M, Suliman HB, Piantadosi CA, Mayhew TM, Breen P (2010) Survival in critical illness is associated with early activation of mitochondrial biogenesis. Am J Respir Crit Care Med 182:745-751

55. Inoue I, Itoh F, Aoyagi S, Tazawa S, Kusama H, Akahane M, Mastunaga T, Hayashi K, Awata T, Komoda T (2002) Fibrate and statin synergistically increase the transcriptional activities of PPARalpha/RXRalpha and decrease the transactivation of NFkappaB. Biochem Biophys Res Commun 290:131-139

56. Hanefeld M, Marx N, Pfutzner A, Baurecht W, Lubben G, Karagiannis E, Stier U, Forst T (2007) Anti-inflammatory effects of pioglitazone and/or simvastatin in high cardiovascular risk patients with elevated high sensitivity C-reactive protein: the PIOSTAT Study. J Am Coll Cardiol 49:290-297

57. Li YG, Zhu W, Tao JP, Xin P, Liu MY, Li JB, Wei M (2013) Resveratrol protects cardiomyocytes from oxidative stress through SIRT1 and mitochondrial biogenesis signaling pathways. Biochem Biophys Res Commun 438:270-276

58. Manna SK, Mukhopadhyay A, Aggarwal BB (2000) Resveratrol suppresses TNF-induced activation of nuclear transcription factors NF-kappa B, activator protein-1, and apoptosis: potential role of reactive oxygen intermediates and lipid peroxidation. J Immunol 164:6509-6519

59. Merx MW, Liehn EA, Janssens U, Lutticken R, Schrader J, Hanrath P, Weber C (2004) HMG-CoA reductase inhibitor simvastatin profoundly improves survival in a murine model of sepsis. Circulation 109:2560-2565

60. Merx MW, Liehn EA, Graf J, van de Sandt A, Schaltenbrand M, Schrader J, Hanrath P, Weber C (2005) Statin treatment after onset of sepsis in a murine model improves survival. Circulation 112:117-124

61. Yasuda H, Yuen PS, Hu X, Zhou H, Star RA (2006) Simvastatin improves sepsis-induced mortality and acute kidney injury via renal vascular effects. Kidney Int 69:1535-1542

62. Stolf AM, Livero Fdos R, Dreifuss AA, Bastos-Pereira AL, Fabosi IA, Alves de Souza CE, Gomes Lde O, Chicorski R, Brandt AP, Cadena SM (2012) Effects of statins on liver cell function and inflammation in septic rats. J Surg Res 178:888-897

63. Hackam DG, Mamdani M, Li P, Redelmeier DA (2006) Statins and sepsis in patients with cardiovascular disease: a population-based cohort analysis. Lancet 367:413-418

64. Thomsen RW, Riis A, Kornum JB, Christensen S, Johnsen SP, Sorensen HT (2008) Preadmission use of statins and outcomes after hospitalization with pneumonia: population-based cohort study of 29,900 patients. Arch Intern Med 168:2081-2087

65. Kruger P, Fitzsimmons K, Cook D, Jones M, Nimmo G (2006) Statin therapy is associated with fewer deaths in patients with bacteraemia. Intensive Care Med 32:75-79

66. Liappis AP, Kan VL, Rochester CG, Simon GL (2001) The effect of statins on mortality in patients with bacteremia. Clin Infect Dis 33:1352-1357

67. Vandermeer ML, Thomas AR, Kamimoto L, Reingold A, Gershman K, Meek J, Farley MM, Ryan P, Lynfield R, Baumbach J (2012) Association between use of statins and mortality among patients hospitalized with laboratoryconfirmed influenza virus infections: a multistate study. J Infect Dis 205:13-19

68. Yende S, Milbrandt EB, Kellum JA, Kong L, Delude RL, Weissfeld LA, Angus DC (2011) Understanding the potential role of statins in pneumonia and sepsis. Crit Care Med 39:1871-1878

69. van den Hoek HL, Bos WJ, de Boer A, van de Garde EM (2011) Statins and prevention of infections: systematic review and meta-analysis of data from large randomised placebo controlled trials. BMJ 343:d7281

70. Becker K, Tanzi P, Kalil A, Shibata D, Cain K (2011) Early statin use is associated with increased risk of infection after stroke. J Stroke Cerebrovasc Dis 22(1):66-71

71. Novack V, Eisinger M, Frenkel A, Terblanche M, Adhikari NK, Douvdevani A, Amichay D, Almog Y (2009) The effects of statin therapy on inflammatory cytokines in patients with bacterial infections: a randomized double-blind placebo controlled clinical trial. Intensive Care Med 35:1255-1260

72. Patel JM, Snaith C, Thickett DR, Linhartova L, Melody T, Hawkey P, Barnett AH, Jones A, Hong T, Cooke MW (2012) Randomized double-blind placebo-controlled trial of $40 \mathrm{mg} /$ day of atorvastatin in reducing the severity of sepsis in ward patients (ASEPSIS Trial). Crit Care 16:R231

73. Kruger P, Bailey M, Bellomo R, Cooper DJ, Harward M, Higgins A, Howe B, Jones D, Joyce C, Kostner K (2013) A multicenter randomized trial of atorvastatin therapy in intensive care patients with severe sepsis. Am J Respir Crit Care Med 187:743-750

74. Kruger PS, Harward ML, Jones MA, Joyce CJ, Kostner KM, Roberts MS, Venkatesh B (2011) Continuation of statin therapy in patients with presumed infection: a randomized controlled trial. Am J Respir Crit Care Med 183:774-781

75. Shyamsundar M, McKeown ST, O'Kane CM, Craig TR, Brown V, Thickett DR, Matthay MA, Taggart CC, Backman IT, Elborn JS (2009) Simvastatin decreases lipopolysaccharide-induced pulmonary inflammation in healthy volunteers. Am J Respir Crit Care Med 179:1107-1114

76. Budd A, Alleva L, Alsharifi M, Koskinen A, Smythe V, Mullbacher A, Wood J, Clark I (2007) Increased survival after gemfibrozil treatment of severe mouse influenza. Antimicrob Agents Chemother 51:2965-2968

77. Castillero E, Nieto-Bona MP, Fernandez-Galaz C, Martin Al, Lopez-Menduina M, Granado M, Villanua MA, Lopez-Calderon A (2011) Fenofibrate, a PPAR\{alpha\} agonist, decreases atrogenes and myostatin expression and improves arthritis-induced skeletal muscle atrophy. Am J Physiol Endocrinol Metab 300:E790-799 
78. Standage SW, Caldwell CC, Zingarelli B, Wong HR (2012) Reduced peroxisome proliferator-activated receptor alpha expression is associated with decreased survival and increased tissue bacterial load in sepsis. Shock 37:164-169

79. Padfield KE, Astrakas LG, Zhang Q, Gopalan S, Dai G, Mindrinos MN, Tompkins RG, Rahme LG, Tzika AA (2005) Burn injury causes mitochondrial dysfunction in skeletal muscle. Proc Natl Acad Sci USA 102:5368-5373

80. Kaplan JM, Cook JA, Hake PW, O'Connor M, Burroughs TJ, Zingarelli B (2005) 15-Deoxy-delta(12,14)-prostaglandin $\mathrm{J}(2)$ (15D-PGJ(2)), a peroxisome proliferator activated receptor gamma ligand, reduces tissue leukosequestration and mortality in endotoxic shock. Shock 24:59-65

81. Collin M, Patel NS, Dugo L, Thiemermann C (2004) Role of peroxisome proliferator-activated receptor-gamma in the protection afforded by 15-deoxydelta12,14 prostaglandin $\mathrm{J} 2$ against the multiple organ failure caused by endotoxin. Crit Care Med 32:826-831

82. Drosatos K, Khan RS, Trent CM, Jiang H, Son NH, Blaner WS, Homma S, Schulze PC, Goldberg IJ (2013) Peroxisome proliferator-activated receptor-gamma activation prevents sepsis-related cardiac dysfunction and mortality in mice. Circ Heart Fail 6:550-562

83. Schaller G, Kolodjaschna J, Pleiner J, Mittermayer F, Kapiotis S, Schmetterer L, Wolzt M (2008) Pioglitazone does not affect vascular or inflammatory responses after endotoxemia in humans. Horm Metab Res 40:549-555

84. Singh S, Loke YK, Furberg CD (2011) Long-term use of thiazolidinediones and the associated risk of pneumonia or lower respiratory tract infection: systematic review and meta-analysis. Thorax 66:383-388

85. Nissen SE, Wolski K (2007) Effect of rosiglitazone on the risk of myocardial infarction and death from cardiovascular causes. N Engl J Med 356:2457-2471

86. Moseley CE, Webster RG, Aldridge JR (2010) Peroxisome proliferator-activated receptor and AMP-activated protein kinase agonists protect against lethal influenza virus challenge in mice. Influenza Other Respi Viruses 4:307-311

87. Majer O, Bourgeois C, Zwolanek F, Lassnig C, Kerjaschki D, Mack M, Muller M, Kuchler K (2012) Type I interferons promote fatal immunopathology by regulating inflammatory monocytes and neutrophils during Candida infections. PLoS Pathog 8:e1002811

88. Mofarrahi M, Sigala I, Guo Y, Godin R, Davis EC, Petrof B, Sandri M, Burelle Y, Hussain SN (2012) Autophagy and skeletal muscles in sepsis. PLoS One 7:e47265

89. Miglio G, Rosa AC, Rattazzi L, Collino M, Lombardi G, Fantozzi R (2009) PPARgamma stimulation promotes mitochondrial biogenesis and prevents glucose deprivation-induced neuronal cell loss. Neurochem Int 55:496-504

90. Aldridge JR, Jr, Moseley CE, Boltz DA, Negovetich NJ, Reynolds C, Franks J, Brown SA, Doherty PC, Webster RG, Thomas PG (2009) TNF/iNOS-producing dendritic cells are the necessary evil of lethal influenza virus infection Proc Natl Acad Sci USA 106:5306-5311

91. Potula R, Ramirez SH, Knipe B, Leibhart J, Schall K, Heilman D, Morsey B, Mercer A, Papugani A, Dou H (2008) Peroxisome proliferator-activated receptor-gamma activation suppresses HIV-1 replication in an animal model of encephalitis. AIDS 22:1539-1549

doi:10.1186/2197-425X-2-9

Cite this article as: Morel and Singer: Statins, fibrates, thiazolidinediones and resveratrol as adjunctive therapies in sepsis: could mitochondria be a common target? Intensive Care Medicine Experimental 2014 2:9.

\section{Submit your manuscript to a SpringerOpen ${ }^{\circ}$ journal and benefit from:}

- Convenient online submission

Rigorous peer review

- Immediate publication on acceptance

- Open access: articles freely available online

- High visibility within the field

- Retaining the copyright to your article

Submit your next manuscript at $\boldsymbol{\nabla}$ springeropen.com 